\title{
Aspects of the reproductive biology, movements and site fidelity of right whales off Australia
}

\author{
STEPHEN R. Burnell \\ Australian Marine Mammal Research Centre, University of Sydney, clo 25 Seaview Road, Tennyson, SA 5022, Australia \\ Contact e-mail: sburnell@bigfoot.com
}

\begin{abstract}
Between 1991 and 1997 right whales were studied on their wintering grounds on the southern coastline of Australia, predominantly at the Head of the Great Australian Bight, where over 350 individuals have been identified. The observed mean inter-calf interval for females was $3.33 \pm 0.10$ years $( \pm \mathrm{SE}, n=57)$ at the Head of the Bight and $3.64 \pm 0.13$ years $( \pm \mathrm{SE}, n=117)$ in the wider Australian population. When inter-calf intervals of six or more years were excluded, the mean intervals became $3.28 \pm 0.09$ years $( \pm \mathrm{SE}, n=56)$ and $3.28 \pm 0.06$ years $( \pm \mathrm{SE}$, $n=107$ ), respectively. Inter-calf intervals of two years were recorded following the early death of a neonate on two separate occasions and the implications of these 'shortened' intervals and of calvings that were not observed are discussed. The mean age at which yearlings were observed to be fully weaned was calculated to be $365 \pm 8$ days ( \pm SE, $n=18$ ) from the estimated birth dates of individual calves and subsequent associations, or lack of them, between the yearlings and their cows the following year. A total of 108 movements greater than $200 \mathrm{~km}$ in length were made by individual whales. The mean within-year movement was $730 \pm 84 \mathrm{~km}$, made over $34 \pm 4$ days $( \pm \mathrm{SE}, n=18)$, whilst the mean between-year movement was $1,036 \pm 45 \mathrm{~km}( \pm \mathrm{SE}, n=87)$, made over a mean interval of $3.3 \pm 0.3$ years $( \pm \mathrm{SE}, n=90)$. The number and direction of coastal movements observed suggest that the right whales off southern Australia comprise a single population which may undertake an almost circular, anti-clockwise migration to the south of the Australian continent. A significantly greater proportion of females displayed a level of between-year fidelity to the Head of the Bight aggregation area $(92 \%, n=61)$ than did males $(68 \%, n=19)$ or whales of unknown sex $(63 \%, n=8)$.
\end{abstract}

KEYWORDS: RIGHT WHALE; REPRODUCTION; MOVEMENTS; SITE FIDELITY; AUSTRALASIA

\section{INTRODUCTION}

Right whales (Eubalaena sp.) in both hemispheres were subject to severe hunting pressure prior to the twentieth century. Australia was no exception, with shore-based and pelagic whaling taking at least 26,000 right whales from the region between 1822 and 1930 (Dawbin, 1986).

Population levels prior to exploitation have proved impossible to estimate with any confidence (see IWC, 2001b), although Braham and Rice (1984) suggest a world-wide abundance for the genus of between 100,000 and 300,000 prior to the $15^{\text {th }}$ century with an estimated $80 \%$ of these in the Southern Hemisphere. Southern right whales $(E$. australis) winter on the southern coastlines of the African, South American and Australian continents, along with the coast of New Zealand and oceanic islands such as the Tristan da Cunha, Auckland and Campbell Island groups. The extent of the species' migration and the location of the summer feeding grounds have never been known with any certainty. The long delay in recovery of the Australian population between its supposed protection in 1935 and the first sign of any measurable recovery in the late 1970s has been puzzling, particularly given the fact that whaling for the species off Australia virtually ceased in the mid 1800s. However, the recent evidence of extensive and illegal whaling operations carried out by the former Soviet Union throughout the 1950s, 1960s and early 1970s (Yablokov, 1994; Tormosov et al., 1998) may have effectively solved this puzzle.

The southern right whale remains classified as 'vulnerable' by the World Conservation Union (IUCN) and is a listed species under Australia's Endangered Species legislation. The protection and monitoring of the recovering southern right whale population is considered a high priority by Australian Government conservation authorities (e.g. Bannister et al., 1996).

Right whales are found close to the southern Australian coastline during the austral winter, between May and November. One of the largest and most consistent aggregation areas lies at the Head of the Great Australian
Bight, on the west coast of South Australia (31 $28^{\prime}$ 'S, $\left.131^{\circ} 08^{\prime} \mathrm{E}\right)$ where shore-based observations of right whales have been undertaken since 1991 (Burnell and Bryden, 1997).

\section{Reproduction}

The small sizes of the remnant populations, combined with complete protection, have meant that long-term studies of living right whales are required to determine reproductive parameters such as reproductive rates, age at first parturition and the duration of gestation and lactation. Such studies, carried out in the North and South Atlantic, and Southern Oceans, have found female reproductive (inter-calf) intervals of three years to be the most common in both the southern and North Atlantic right whale (E. glacialis), with intervals of two and four or more years being detected much less frequently (Bannister, 1990; Best, 1990a; Payne et al., 1990; Knowlton et al., 1994; Best et al., 2001; Cooke et al., 2001). Post-partum ovulation does not appear to occur in right whales and no published record exists of a female right whale giving birth in consecutive years.

Most mysticetes are thought to wean their young within a year (Lockyer, 1984). Data collected during whaling operations indicated a mean age of weaning of 10.5 months for Southern Hemisphere humpback whales, Megaptera novaeangliae (Chittleborough, 1958) and 6-9 months for Pacific gray whales, Eschrichtius robustus (Rice and Wolman, 1971; Yablokov and Bogoslovskaya, 1984). Until recently, the only such whaling data available from right whales was Klumov's (1962) estimate of 6-7 months for the age of weaning in the northern right whale in the North Pacific. This estimate was based on the presence of copepods in the stomachs of two immature whales killed and assumed from their length (approximately 11 metres) to have been born the previous winter. However, recent data from illegal Soviet catches in the 1960 s showed lactation to last at least 7-8 months (Tormosov et al., 1998). Further, Hamilton et al. (1995) describe three juvenile northern right whales in the 
northwest Atlantic that were weaned between 8 and 17 months after the estimated peak of calving in that population. The only well documented age of weaning in right whales is based on the photo-identification of a single neonate and its subsequent resighting the following year, as described by Thomas and Taber (1984). This individual was a minimum of 412 days old when weaned at Peninsula Valdes, Argentina.

\section{Movements and fidelity}

Although right whales range along the entire temperate coastline of Australia during the winter and spring months, their spatial distribution is quite clumped. Several aggregation areas are characterised by their consistent use by relatively dense concentrations of right whales. Bannister (1990) reports the high incidence of right whales off four broad, but distinct, regions of the south coast of Western Australia. Similarly, sightings off southeastern Australia, particularly of calving females, appear to be clumped (Ling and Needham, 1991; Burnell, 1997; Burnell and Bryden, 1997).

The occurrence or nature of any population sub-division within the 'Australian' population is unknown. The delineation of a southeastern and southwestern Australian stock has been proposed (Brownell et al., 1986), although this was biologically unfounded and appears to have been done primarily for management purposes. What it is that attracts right whales to particular areas on these coastlines is still not well understood. Fidelity to calving and feeding grounds has been observed in a range of mysticetes and is summarised well in Donovan (1986). Individual gray and right whale females are known to return repeatedly to specific coastal areas during winter to calve and rear their young; gray, humpback, bowhead (Balaena mysticetus) and North Atlantic right whales have been observed to return consistently to core feeding areas also (Darling, 1984; Donovan, 1986). Site fidelity can be displayed on a wide range of scales, from a small lagoon or aggregation area to whole ocean regions $\left(10 \mathrm{~s}-100,000 \mathrm{~s} \mathrm{~km}^{2}\right)$, although the geographic level to which fidelity is displayed is difficult to quantify and thus rarely attempted.

This paper reports on several aspects of the reproductive biology, movements and site fidelity of right whales along the southern Australian coast. In particular, data are presented on: the reproductive capacity of the population; the age at which yearlings are weaned; medium- and long-range coastal movements; and the relative fidelity shown to the Head of Bight aggregation area by individual right whales.

\section{METHODS}

The majority of data collection was undertaken at the Head of the Great Australian Bight between 1991 and 1997. This site represents one of the largest and most consistent aggregation and calving areas for this species on the Australian coast, with around a third of all known calves born there. Between 1991 and 1997, more than 350 individual right whales were photographically identified at this site.

Although utilising the same naturally-occurring identifying features, the methodology of photoidentification of individual right whales used at the Head of the Bight differed from most previous studies (Payne et al., 1983; Kraus et al., 1986a; Bannister, 1990; Best, 1990a) in that all identification photography was carried out from shore-based positions. The sea-cliffs at the Head of the Bight aggregation area provide an excellent photographic platform up to $65 \mathrm{~m}$ above sea level, with identification photography enhanced by the willingness of the whales to approach very close to shore at the base of these cliffs.

A benefit of the photographic methodology employed during this study (see Burnell and Bryden, 1997) was the very high resolution achieved, due to both the stability of the photographic platform and the use of super-telephoto lenses. In addition, individual whales were available for photography over longer time periods, due to the lack of any time restrictions imposed by the increased cost and logistical difficulties of aircraft- and vessel-based operations. This resulted in the successful collection of a range of individual specific markers for most of the whales identified, including the determination of the sex of many adults that were not accompanied by calves and of many of the calves themselves. Due to the reduced likelihood of achieving a positive resight based on photographs of the callosities alone, the use of all individual specific identification cues is critical when identifying calves, as noted by Kraus et al. (1986a). Possible matches detected from the callosity pattern were quickly and unquestionably confirmed if a direct match of the unique ventral blaze was also made.

Right whales show no dorsally obvious sexual dimorphism. Determination of the sex of males can only be determined through direct observation/photography of the ano-genital configuration and/or the penis itself, and for females through direct observation/photography of the ano-genital configuration or via the continued close accompaniment of a calf. The extended periods of observation and proximity of the whales meant that the determination of sex was possible for the majority of non-calf whales identified at the Head of the Bight. Although the use of behavioural cues can be, and has been used to infer the sex of individuals (eg. Payne and Dorsey, 1983), these were not used in this study as they often produced an incorrect classification.

All young-of-the-year were classified as 'calves' with the term being reserved for that age-class. A definitive maximum size, in terms of the relative length of one individual to another, was not used to assign 'calf' status. This was due to the large size range possible for southern right whale calves in their birth year (Best and Rüther, 1992); returning yearlings could be of similar size to the larger calves. The duration and frequency of observation produced numerous within-year resightings of most female-calf pairs allowing accurate designation of calves. Similarly, repetitive behavioural observations combined with morphological differences, particularly of the head, meant that large calves were very unlikely to be mistaken for returning yearlings during this study. Immature whales (based on relative length, girth and morphology of the head) were referred to as 'sub-adults' when their age was not known, or as yearlings, two-year-olds etc., when an individual had been identified in its birth year and was thus of known age.

Adult whales not accompanied by a calf were termed 'unaccompanied adults'. This status category contained males, non-calving females and animals of unknown gender; for most analyses all sub-adults and known age juveniles were also included. Females accompanied by calves were termed 'cows' with the combined unit usually referred to as a 'cow-calf pair'.

\section{Reproduction}

The inter-calf (reproductive) intervals of females were determined through longitudinal identification studies which recorded the years in which females were observed 
accompanied by calves and those in which they were not. The status of individual whales identified at the Head of the Bight was recorded on each sighting occasion, with the survey regime usually allowing many confirmations of a female's reproductive status in any given year. To determine the calving interval within the wider population, additional data were available from aerial photographs collected from the Western Australian coastline between 1979 and 1997 (Bannister, 1997) and from identification photographs and data collected off southeastern Australia between 1995 and 1997 (Burnell, 1997). Some additional sightings of females identified in the current study but made at the Head of the Bight aggregation area between 1984 and 1990 (Ling and Needham, 1985) were also included.

The calculated 'age at weaning' represents the age of the individual when it was first observed to be independent of the cow. The use of the date of first sighting of a neonatal calf as its birth date has a tendency to reduce the observed age at weaning, whereas the delay in sighting the independent yearling will tend to increase the observed age at weaning. Both these sightability biases are predicted to be small and they may effectively negate each other. The observed 'age at weaning', although possibly analogous to the 'duration of lactation', is a more accurate description of what has been documented in this study and is thus the preferred descriptor.

\section{Coastal movements}

Movements made by individual right whales around Australia's southern coastline are described and the implications of these movements for the migration and stock delineation of the Australian right whale population discussed. Australia's southern coastline represents an approximate great circle distance of $3,200 \mathrm{~km}$ and a coastal distance of well over $5,000 \mathrm{~km}$, so movements along this coastline can potentially be similar in distance to the long-range oceanic movements described by Best et al. (1993). The distance between resightings made in different calendar years was calculated using the great circle route between the two points, due to the high probability of one or more long-distance, latitudinal migrations to the sub-Antarctic summer feeding grounds taking place between the two coastal sightings (Bannister et al., 1999). Although the time period between the two sightings may have been less than 12 months, the sightings were made in different calendar years, and few if any right whales are sighted in Australian coastal waters during the austral summer (December-February). For convenience, these were termed 'between-year movements', although it is clear that they represent only a small proportion of the individual whale's actual movements between the two sightings.

Movements that occurred within a winter season are predicted to have been made in coastal waters, and the distance between within-year sightings (made in the same calendar year) was calculated using the shortest sea-route (great circle route avoiding land), and termed a "within-year movement'. For these analyses, a distance of $200 \mathrm{~km}$ was chosen as the minimum distance and resightings made less than $200 \mathrm{~km}$ apart have not been included. This distance clearly separates such longer range movements from the short range meanderings and daily movements that whales can make within and around aggregation areas, and which rarely exceed $50 \mathrm{~km}$. The southern Western Australian coastline is referred to as the 'southwest' region; the South Australian coastline to the west of $135^{\circ} \mathrm{E}$, or approximately Port Lincoln, and including the Head of the Bight aggregation area, is referred to as the 'south central' region; and the coastline east of $135^{\circ} \mathrm{E}$ to Sydney in New South Wales, and including Tasmania, as the 'southeast' region, see Fig. 1.

\section{Determining fidelity}

An attempt was made to determine the relative fidelity of individual right whales to the Head of the Bight aggregation area by comparing the number of sightings made within the aggregation area against the combined total number of sightings made at other locations on the Australian coastline. Individual whales were assumed to be displaying some level of fidelity to the Head of the Bight aggregation area when an individual whale has been seen there in at least two separate years, and if so, that the individual has been seen at the Head of the Bight on more occasions than the number of sightings at all other localities combined. For example, a whale seen three times at the Head of the Bight, once at Albany, Western Australia and once at Port Lincoln, South Australia was considered to be displaying some level of fidelity to the Head of the Bight, whereas a whale that has been seen twice at the Head of the Bight as well as at Albany and Esperance in Western Australia and Victor Harbor, South Australia was not considered to be showing any observable fidelity to the Head of the Bight aggregation area (see Fig. 1). Whales that have only ever been seen once at the Head of the Bight and nowhere else were not included as their relative fidelity was indeterminable.

\section{RESULTS}

\section{Reproductive biology}

Inter-calf interval at the Head of the Bight

Between 1991 and 1997, 47 individually identified females were recorded with calves at the aggregation area in two or more separate study years, providing a total of 57 inter-calf intervals for analysis.

Of the 57 inter-calf intervals recorded, two $(3.5 \%)$ were of two years duration, $41(72 \%)$ were of three years, eight $(14 \%)$ were of four years, five $(9 \%)$ were of five years and one $(1.5 \%)$ was of six years, giving a mean interval of $3.33 \pm 0.10$ years $( \pm \mathrm{SE}, n=57)$, for the inter-calf intervals observed during this study. A mean inter-calf interval of 3.33 years equates to a calf production rate of 0.30 calves per mature female per year.

\section{Inter-calf interval in the wider Australian population}

The Head of the Bight aggregation area does not represent a closed population, a fact highlighted by the extent of interchange between coastal regions documented during this study.

The inclusion of data in the form of photographs and sighting details from other regions on the Australian coastline and from the Head of the Bight prior to 1991 allowed an assessment of the inter-calf interval in the wider Australian population. A total of 70 females for which two or more calvings were observed provided 117 inter-calf intervals for analysis.

With the inclusion of these additional data, the mean inter-calf interval observed increased to $3.64 \pm 0.13$ years $( \pm \mathrm{SE}, n=117)$. A mean inter-calf interval of 3.64 years equates to a calf production rate of 0.275 calves per mature female per year.

Early calf mortality, 'missed' calvings and two and five year inter-calf intervals

During this study, two females were observed and photographed whilst accompanied by a neonate, and then observed later in the same season without the calf. One of 
these females 'lost' her calf in two of the three years in which she was observed to calve at the aggregation area, providing data on a total of three neonatal mortalities.

In 1992, female 9216 was observed with a calf on 2 July and then sighted and photographed with the same calf on at least four separate days up to and including 16 September. She was next sighted on 27 September with no accompanying calf and then resighted subsequently on ten separate days up to 6 October, again with no calf. Following the death of her calf in 1992, female 9216 calved again at the aggregation area in 1994. In that year, when first observed on 30 June, she was accompanied by a neonate and then was subsequently sighted on at least six separate days up to and including 1 August accompanied by the calf. On 4 August she was observed alone, and then on at least 13 separate days up to and including 6 September was again observed without a calf. She calved again at the Head of Bight aggregation area in the first week of July 1996, another two year inter-calf interval. Although survey coverage in 1996 was less than in 1992 or 1994, observations were made of 9216 and calf over several days in early July and again on several occasions at the end of August at which time the calf appeared normal in all respects. These observations suggest that the death of a neonate within the first six weeks may have resulted in the female concerned adopting a two year interval prior to the next calving.
A third early calf mortality was observed at the Head of the Bight but it is unknown if the female concerned subsequently exhibited a two year interval. On 27 July 1993, female 9324 was seen alone and then on 10 August was sighted accompanied by a calf estimated to be less than 3 days old (based on size, colouration, presence of foetal skin folds etc.) with which she was observed and photographed over four separate days up to and including 16 August. This female was then seen and photographed over two separate days up to 20 August with no accompanying calf.

Five females recorded a five year inter-calf interval at the Head of the Bight during this study. However, in between these calvings, four of the five were sighted without calves at an interval of three years.

\section{Maximum age at weaning}

Between 1992 and 1995, 17 calves were resighted at the Head of the Bight aggregation area in the year following their birth there. An additional three calves born at the Head of the Bight were resighted as yearlings at other localities on the Australian coastline. Of these 20 yearlings, 13 were resighted alone or interacting with other whales but no sighting of the cow was made in that year, indicating they were already fully weaned at the time of resighting. The cows of another two yearlings were sighted at the aggregation area although never in the company (within

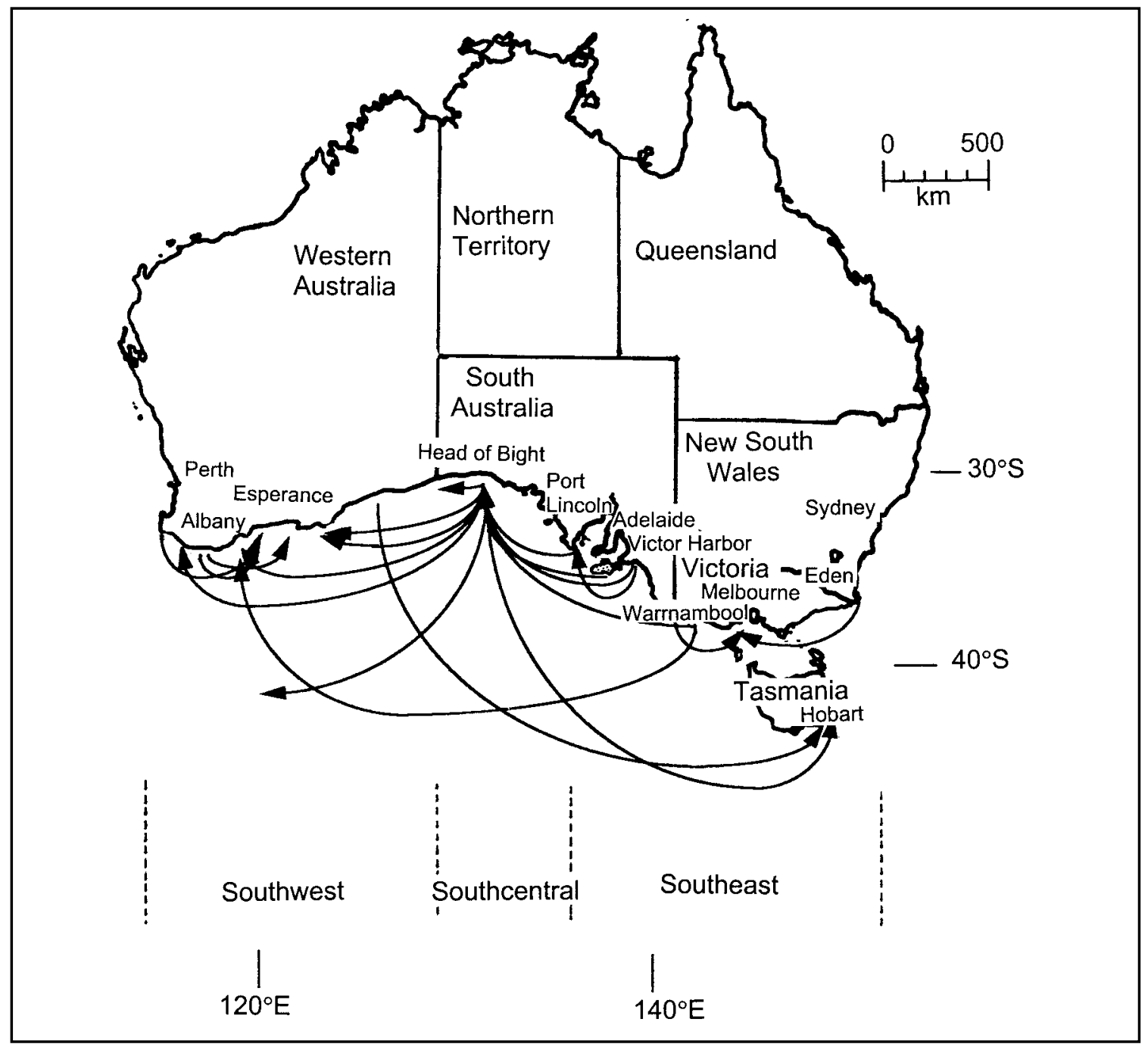

Fig. 1. Examples of movements made by individual right whales off southern Australia. Lines are representative only and are not intended to represent actual track. The positions of the 'southwest', 'southcentral' and 'southeast' zones are shown. 
$500 \mathrm{~m}$ ) of their yearling calf, suggesting that weaning was either taking place at the aggregation area or had occurred recently. Three of the remaining five returning yearlings were seen in the company of the cows initially and then subsequently were seen alone, indicating that some females do return to the aggregation area to wean their yearling calves. The final two yearlings were seen at the aggregation area with their cows (at ages of 344 and 334 days), although they were not subsequently seen alone, so it was not possible to determine where, or at what age, they were fully weaned.

Table 1 provides the sighting dates as both neonatal calves and independent yearlings for the 18 individuals, along with their calculated maximum age when observed to be fully weaned. The ages at which these yearlings were observed to be independent of the cow (fully weaned) ranged from 303 days to 419 days, with a mean of $364.6 \pm 7.8$ days $( \pm \mathrm{SE}$, $n=18$ ) and median of 365.5 days, almost exactly 12 months.

\section{Coastal movements}

A total of 108 movements of greater than $200 \mathrm{~km}$ were made by individual whales, 18 within a calendar year and 90 between years. For all of these movements combined, the mean distance travelled was $983 \pm 42 \mathrm{~km}( \pm$ SE, $n=108)$.

Due to the very different nature of movements made within and between years the two types of 'movements' are treated independently here.

Fig. 2 shows the frequency distributions of distance travelled and provides the mean distance of the two types of movements discussed here. Fig. 1 also shows representative examples of the movements of individual right whales detected off southern Australia during this study.

Appendix 1 contains two tables detailing the within- and between-year coastal movements recorded, and includes the date and location of the relevant sightings and the sex and status in 1995 of the individual if known.

\section{Within-year movements}

The 18 within-year movements ranged in length from $211-1,490 \mathrm{~km}$, and were made over time periods of 3-59 days. The mean within-year movement was $730 \pm 84 \mathrm{~km}$, and made over $34 \pm 4$ days $( \pm \mathrm{SE}, n=18)$. The longest within-year
Table 1

Sighting data for the 20 individuals identified as neonates at the Head of the Bight and resighted as yearlings the following season, including the age at which they were observed independent of the female (fully weaned).

\begin{tabular}{|c|c|c|c|c|}
\hline ID cow & ID calf & $\begin{array}{l}\text { Estimated } \\
\text { birth date }\end{array}$ & $\begin{array}{l}\text { Weaned by } \\
\text { date }\end{array}$ & $\begin{array}{l}\text { Age at which } \\
\text { observed to be fully } \\
\text { weaned (days) }\end{array}$ \\
\hline 9101 & 9125 & 11 Sep. 1991 & $16 \mathrm{Jul} .1992$ & 309 \\
\hline 9105 & 9129 & 31 Aug. 1991 & 3 Jul. 1992 & 307 \\
\hline 9111 & 9135 & 27 Aug. 1991 & $23 \mathrm{Aug} .1992$ & 362 \\
\hline 9119 & 9143 & 21 Aug. 1991 & 26 Aug. 1992 & 371 \\
\hline 9203 & 9236 & 4 Jul. 1992 & 2 Aug. 1993 & 394 \\
\hline 9211 & 9244 & 22 Jul. 1992 & 13 Jul. 1993 & 356 \\
\hline 9308 & 9377 & 16 Jul. 1993 & 13 Jul. 1994 & 362 \\
\hline 9311 & 9380 & 14 Jul. 1993 & $\begin{array}{r}23 \text { Jun. } 1994 \\
\text { (with cow) }\end{array}$ & $>344^{*}$ \\
\hline 9313 & 9382 & 27 Jul. 1993 & 13 Jul. 1994 & 351 \\
\hline 9314 & 9383 & 25 Jul. 1993 & $\begin{array}{r}24 \text { Jun. } 1994 \\
\text { (with cow) }\end{array}$ & $>334^{*}$ \\
\hline 9316 & 9385 & 9 Aug. 1993 & 1 Aug. 1994 & 357 \\
\hline 9323 & 9392 & 24 Aug. 1993 & 23 Jun. 1994 & 303 \\
\hline 9325 & 9394 & 3 Jul. 1993 & 31 Jul. 1994 & 393 \\
\hline 9121 & 9395 & 17 Aug. 1993 & 2 Aug. 1994 & 350 \\
\hline 9403 & 9462 & 27 Jun. 1994 & 15 Jul. 1995 & 383 \\
\hline 9101 & 9471 & 23 Sep. 1994 & 27 Sep. 1995 & 369 \\
\hline 9106 & 9474 & 21 Jul. 1994 & 26 Aug. 1995 & 401 \\
\hline 9113 & 9478 & 27 Jun. 1994 & 20 Aug. 1995 & 419 \\
\hline 9114 & 9479 & 29 Jun. 1994 & 8 Jul. 1995 & 374 \\
\hline \multirow[t]{2}{*}{9116} & 9480 & 24 Jul. 1994 & 30 Aug. 1995 & 402 \\
\hline & & & Mean $( \pm$ SE $)=$ & $364.6 \pm 7.8$ \\
\hline
\end{tabular}

* Values not included in calculation of the mean and median, because yearlings not sighted independently of cow.

movement was made by a female (9228) that travelled from the Head of the Bight $\left(31^{\circ} 28^{\prime} \mathrm{S}, 131^{\circ} 08^{\prime} \mathrm{E}\right)$ southwest to Point D'Entrecasteaux, Western Australia (3450'S, $\left.116^{\circ} 00^{\prime} \mathrm{E}\right)$, a distance of $1,490 \mathrm{~km}$ in 41 days or less, at a minimum average travel speed of $1.51 \mathrm{~km} / \mathrm{h}$. This small female was sighted in three consecutive study years at the Head of the Bight aggregation area, although never with a calf, and is likely to be immature. On 22 July 1994, a single adult (9452) was photographed at Portland, Victoria $\left(38^{\circ} 20^{\prime} \mathrm{S}, 141^{\circ} 37^{\prime} \mathrm{E}\right)$ and was identified 49 days later at the Head of the Bight, on 9 September 1994, a distance of $1,297 \mathrm{~km}$ northwest, where it remained for the next three

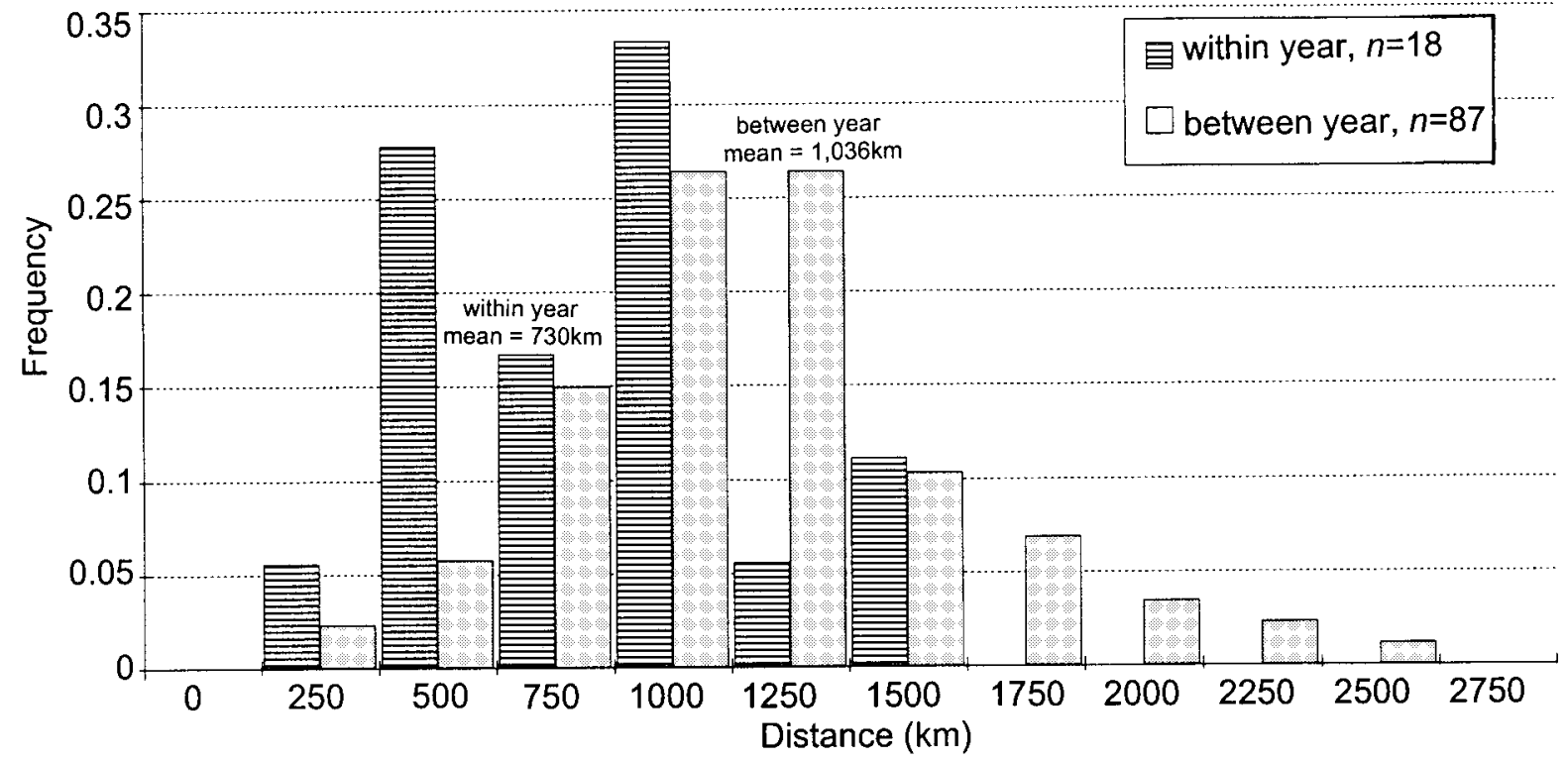

Fig. 2. Frequency distribution of the 18 within-year and 87 between-year (for which distance known) movements made by individual right whales during this study. 
weeks. The minimum average travel speed was $1.10 \mathrm{~km} / \mathrm{h}$. The fastest within-year movement recorded, with a minimum average speed of $3.66 \mathrm{~km} / \mathrm{h}$, was made by a sub-adult $(95 \mathrm{~N} 1)$ that travelled $351 \mathrm{~km}$ east from Nelson, Victoria $\left(38^{\circ} 06^{\prime} \mathrm{S}, 141^{\circ} 00^{\prime} \mathrm{E}\right)$ to Anglesea, Victoria $\left(38^{\circ} 25^{\prime} \mathrm{S}, 144^{\circ} 12^{\prime} \mathrm{E}\right)$ in less than 4 days.

All of the movements described above were made by unaccompanied whales. Only one record of a within-year movement by a female accompanied by a calf was obtained. Female 9409 and calf, sighted at Port Lincoln, South Australia $\left(34^{\circ} 40^{\prime} \mathrm{S}, 135^{\circ} 53^{\prime} \mathrm{E}\right)$ on 3 August 1994, was observed on 3 September at the Head of the Bight, $704 \mathrm{~km}$ away, where they remained for five weeks.

Three of the 18 within-year movements $(16.7 \%)$ were made in an easterly direction, two of them off the southern Western Australian coastline and one off the Victorian coast. All three were between $200 \mathrm{~km}$ and $400 \mathrm{~km}$, being at the lower end of the range of within-year movements. Within-year movements made to the east were significantly shorter than those made to the west (Kruskall-Wallis ANOVA, $\left.\mathrm{H}_{1}=4.8, \mathrm{p}<0.05\right)$. Also, as might be expected, there was a significant correlation between the distance travelled and the time period separating the two sightings (Spearman ranked correlation, $\mathrm{R}=0.627, p<0.01$ ).

\section{Between-year movements}

The 90 between-year movements were made by 63 individual whales, and ranged from $210 \mathrm{~km}-2,287 \mathrm{~km}$ and over time periods between one and 18 years.

Due to three movements being from unknown localities on the Western Australian coastline, only 87 between-year movements are available for distance analysis. The mean between-year movement was $1,036 \pm 45 \mathrm{~km}( \pm \mathrm{SE}, n=87)$, significantly greater than the mean within-year movement, (independent t-test, $\mathrm{t}_{103}=-2.87, p<0.05$ ), see Fig. 2 .

The mean time interval separating between-year sightings was $3.3 \pm 0.3$ years $( \pm \mathrm{SE}, n=90)$. The longest single movement between consecutive sightings was between Point Culver, Western Australia (33 $\left.00^{\circ} \mathrm{S}, 1^{\circ} 4^{\circ} 45^{\prime} \mathrm{E}\right)$ and Swansea, Tasmania $\left(42^{\circ} 07^{\prime} \mathrm{S}, 148^{\circ} 05^{\prime} \mathrm{E}\right)$, a great circle distance of $2,287 \mathrm{~km}$. These sightings were made in consecutive years. This same individual (94FN1) recorded the longest series of combined movements, travelling a minimum of $4,746 \mathrm{~km}$ over a six-year period.

A female (9308), that calved at the Head of the Bight in 1993, and was resighted there in 1994 , was photographed $1,505 \mathrm{~km}$ southwest of there at $42^{\circ} 02^{\prime} \mathrm{S}, 120^{\circ} 30^{\prime} \mathrm{E}$, on 14 December 1995. Observations made during the December sighting recorded dense swarms of crustacea in the region and several of the right whales sighted were observed feeding and defecating (see Bannister et al., 1999).

Fifty of the $90(55.6 \%)$ between-year movements were made by females, $24(26.7 \%)$ by males and $16(17.7 \%)$ by whales of unknown sex. There were no significant differences between the length, time or direction of the between-year movements made by these different sex-classes.

The 50 between-year movements of females were made by 35 individual whales, of which 26 were observed to be accompanied by calves on at least one occasion and thus sexually mature. Thirteen of these mature females have been observed to alter calving locations between subsequent births, with one individual (9205) altering calving location on two separate occasions. The longest distance between consecutive calving events was recorded for female 93F1, which calved and remained resident at Hassell Beach, Western Australia (34 $\left.50^{\prime} \mathrm{S}, 118^{\circ} 25^{\prime} \mathrm{E}\right)$ in 1990 and then in
1993 calved and remained resident at Fowlers Bay, South Australia, (31 $\left.{ }^{\circ} 57^{\prime} \mathrm{S}, 132^{\circ} 35^{\prime} \mathrm{E}\right), 1,353 \mathrm{~km}$ to the northeast. This whale was not sighted in the intervening years.

\section{Fidelity to the Head of the Bight aggregation area}

Tables 2 and 3 summarise the number of times each of 61 calving females and 61 unaccompanied adults have been sighted at the Head of the Bight aggregation area along with the number of times they have been sighted at other localities on the Australian coast.

Table 2

The number of times each of 61 calving females have been sighted at the Head of the Bight aggregation area along with the number of times they have been sighted at other localities on the Australian coast. Bold values represent the number of individuals considered to be displaying some level of fidelity to the Head of the Bight (HOB)

\begin{tabular}{ccccc}
\hline $\begin{array}{c}\text { Number of years } \\
\text { sighted at HOB }\end{array}$ & $\begin{array}{c}\text { Sighted } \\
\text { nowhere else }\end{array}$ & $\begin{array}{c}\text { Sighted 1x } \\
\text { elsewhere }\end{array}$ & $\begin{array}{c}\text { Sighted 2x } \\
\text { elsewhere }\end{array}$ & $\begin{array}{c}\text { Sighted 3x } \\
\text { elsewhere }\end{array}$ \\
\hline 1 & Not used & 3 & 1 & 0 \\
2 & $\mathbf{2 8}$ & $\mathbf{2}$ & 0 & 0 \\
3 & $\mathbf{1 0}$ & $\mathbf{6}$ & $\mathbf{3}$ & 1 \\
4 & $\mathbf{3}$ & $\mathbf{2}$ & 0 & 0 \\
5 & $\mathbf{1}$ & $\mathbf{1}$ & 0 & 0 \\
Total & $42(\mathbf{4 2})$ & $14(\mathbf{1 1})$ & $4(\mathbf{3})$ & $1(0)$ \\
\hline
\end{tabular}

Table 3

Sighting history of the 61 unaccompanied adults (14 females, 19 males, 20 calves and 8 of unknown sex) that satisfied the criteria for fidelity analysis. Bold values represent the number of individuals considered to be displaying some level of fidelity to the Head of the Bight (HOB).

\begin{tabular}{ccccc}
\hline $\begin{array}{l}\text { Number of years } \\
\text { sighted at HOB }\end{array}$ & $\begin{array}{c}\text { Sighted } \\
\text { nowhere else }\end{array}$ & $\begin{array}{c}\text { Sighted 1x } \\
\text { elsewhere }\end{array}$ & $\begin{array}{c}\text { Sighted 2x } \\
\text { elsewhere }\end{array}$ & $\begin{array}{c}\text { Sighted 3x } \\
\text { elsewhere }\end{array}$ \\
\hline 1 & Not used & 8 & 3 & 1 \\
2 & $\mathbf{1 9}$ & $\mathbf{8}$ & 2 & 0 \\
3 & $\mathbf{8}$ & $\mathbf{5}$ & $\mathbf{1}$ & 0 \\
4 & $\mathbf{3}$ & 0 & $\mathbf{2}$ & 0 \\
5 & $\mathbf{1}$ & 0 & 0 & 0 \\
\hline & Sighted & Sighted 1x & Sighted 2x & Sighted 3x \\
By sex/status & nowhere else & elsewhere & elsewhere & elsewhere \\
\hline Males, $n=19$ & $\mathbf{8}$ & $8(\mathbf{4})$ & $3(\mathbf{1})$ & 0 \\
Non-calving & $\mathbf{5}$ & $5(\mathbf{5})$ & $3(\mathbf{2})$ & 1 \\
females, $n=14$ & & & & 0 \\
Calves, $n=20$ & $\mathbf{1 4}$ & $6(\mathbf{3})$ & 0 & 0 \\
Unsexed, $n=8$ & $\mathbf{4}$ & $2(\mathbf{1})$ & 2 & $1(\mathbf{0})$ \\
Total & $31(\mathbf{3 1})$ & $21(\mathbf{1 3})$ & $8(\mathbf{3})$ & \\
\hline
\end{tabular}

Of the 85 females which calved at the Head of the Bight aggregation area between 1991 and 1995, 61 have been included in this analysis of relative fidelity. Twenty-four females were excluded because they have only been seen once at the Head of the Bight aggregation area and nowhere else, making their relative fidelity indeterminable. Of these 61 females, 56 (92\%) displayed some level of fidelity to the Head of the Bight aggregation area as defined by the criteria given in the methods.

Coincidentally, there also exist 61 identified unaccompanied whales in the Head of the Bight catalogue that have sightings histories suitable for this analysis. Of these, $46(75 \%)$ show some level of fidelity to the Head of the Bight aggregation area. This is a significantly lower proportion than for the calving females (Yates corrected $\left.\chi^{2}=9.29, p<0.005\right)$.

The unaccompanied whale category was further divided into known males, known females that have never been observed to calve at the Head of the Bight aggregation area, 
calves identified at the Head of the Bight and subsequently resighted, and whales of unknown sex.

Seventeen of the 20 calves $(85 \%)$ displayed some level of fidelity to their birth site and 12 of the $14(86 \%)$ females never observed to calve at the Head of the Bight showed fidelity to the aggregation area. Neither of these groups differed significantly in relative fidelity from females that had calved at the aggregation area (Yates corrected $\chi^{2}=1.77,1.25, p>0.25,0.18$, respectively). However, of the 19 known males meeting the sighting criteria, only $13(68 \%)$ displayed fidelity to the Head of the Bight, significantly fewer than for calving females, non-calving females or juveniles (Yates corrected $\chi^{2}=16.5,8.2,7.1$ respectively, all $p<0.01)$. The fidelity of whales of unknown sex to the Head of the Bight $(63 \%)$ was not significantly different from that of known males (Yates corrected $\chi^{2}=0.35, p>0.55$ ).

\section{DISCUSSION}

\section{Reproductive biology}

Klumov (1962) estimated a duration of gestation of 11-11.5 months for northern right whales in the North Pacific, back-calculated from estimates of the age of two immature whales at the time of their death and the growth rates of two foetuses. Donnelly (1969) estimated a gestation period of 10 months for southern right whales, based on behavioural observations of peaks in 'courtship' and calving off South Africa.

However, Best (1994) using a regression of foetal length measurements obtained from whaling data against their date of death, and an extrapolated estimate of the mean date of calving off South Africa, proposed a gestation period lasting between 357 and 396 days for southern right whales, and predicted that at least some conceptions occur within coastal waters. Burnell and Bryden (1997) suggest a gestation period in the order of 355 days at the Head of the Bight, Australia, based on behavioural observations of mating activity and the observed mean date of calving within that population. Both estimates are suggestive of an approximate 12 month gestation period for this species.

Although right whales off Australia and South Africa calve in the austral winter, the timing of calving may differ between these populations. Burnell and Bryden (1997) calculated a mean date of calving of 16 July at the Head of the Bight aggregation area, considerably earlier than Best's (1994) estimate of 24 August at De Hoop, South Africa.

The only previous estimate of the mean calving interval within the Australian population of 3.14 years \pm 0.84 years $( \pm 2 \mathrm{SE}, n=21)$ is from aerial surveys of the Western Australian coastline (Bannister, 1990). However, an error exists in the presentation of these data with the actual interval being 3.48 years \pm 0.52 years $( \pm 2 \mathrm{SE}, n=21)$.

The mean calving intervals recorded during this study of $3.33 \pm 0.10$ years $( \pm$ SE, $n=57)$ at the Head of the Bight aggregation area and $3.64 \pm 0.13$ years $( \pm \mathrm{SE}, n=117)$ in the wider Australian population, are comparable with those recorded for other populations.

Best (1990a) reports an inter-calf interval, adjusted for biases between survey areas and against longer intervals, of 3.18 years $(\mathrm{SD}=0.09$ years, $n=139)$ off South Africa. Best et al. (2001) updated this estimate to 3.12 years $(95 \% \mathrm{CI}$ 3.07, 3.17). Cooke et al.'s (2001) finding of a mean calving interval of 3.35 years ( $\mathrm{SE}=0.05$ years) at Peninsula Valdes, and Knowlton et al.'s (1994) estimate of the mean calving interval in the North Atlantic population of 3.67 years $(\mathrm{SE}=0.11$ years, $n=86)$ are both comparable with the $3.64 \pm 0.13$ years $( \pm \mathrm{SE}, n=117)$ recorded in the wider
Australian population. Kraus et al. (2001) reported, however, that the calving interval for the North Atlantic has increased to over 5 years for the 1993-98 period.

It is clear that three-year inter-calf intervals are the most common for right whales off Australia with $72 \%$ of observed intervals at the Head of the Bight and $68 \%$ of the intervals in the wider Australian population being of three years duration. However, the proportion of four year inter-calf intervals observed at the Head of the Bight (14\%) and in the wider population (15\%) suggests that a noteworthy proportion of females do routinely calve on a four year cycle.

It is likely that most, if not all, of the six year inter-calf intervals recorded in this study are a result of a failure to detect an intervening calving at three years. Similarly, inter-calf intervals greater than six years are likely to be artefacts caused by a failure to observe one or more intervening calvings. If intervals of six or more years are excluded from the calculations, the mean inter-calf interval at the Head of the Bight becomes 3.28 \pm 0.09 years $( \pm \mathrm{SE}$, $n=56)$ identical to the figure in the wider population, $3.28 \pm 0.06$ years $( \pm \mathrm{SE}, n=107)$.

The two- and five-year inter-calf intervals observed in this species are possibly anomalous, resulting from the abortion or early loss of a calf. Although infrequent, inter-calf intervals of two years have been observed off South Africa (Best, 1990a), Argentina (Payne et al., 1990), Western Australia (Bannister, 1990) and the northeastern United States (Kraus et al., 1986b; Knowlton et al., 1994). Data presented in this study are suggestive of right whale calves being weaned close to 12 months of age meaning a two year inter-calf interval would require almost immediate post-lactation ovulation by the female if gestation is of the order of 12 months as discussed above.

It seems likely that such 'early' ovulation is only likely to occur in right whales following the premature loss of the previous calf, and the subsequent lessening of the physiological depletion of the female. Humpback whales appear to begin oestrous cycles immediately after the premature loss of a calf (Chittleborough, 1958), and Jones (1990) suggests that post-partum ovulation in the gray whale is only likely to occur after the abortion or early loss of a calf, allowing births in successive years rather than the normal two-year interval of that species.

If this is the case with female right whales, the frequency of two-year calving intervals in the population should provide some indication of the level of early neonatal mortality. However, the detection of such two-year intervals is severely hindered by the limited time that the female is available to be recorded in the company of a calf prior to its death, with monthly aerial survey regimes being unlikely to record these calvings. Further, stillborn or miscarried calves would be completely undetectable as would any additional mortality on the calves' first southward migration. Under such conditions, five year inter-calf intervals may be indicative of the early loss or abortion of the intervening calf at three years going undetected, followed by a two-year interval. Cooke et al. (2001) also postulate this as the most likely explanation for the relatively large proportion of five year calving intervals in Argentina. It is relatively unusual to sight females at the Head of the Bight in non-calving years and it is noteworthy that of the five females which recorded five-year intervals at the Head of the Bight, four were sighted after three years, but were not recorded with calves. The likelihood seems strong that these females had failed calvings at three years which were not observed, before successfully calving at five years. 
If this were the case, it could be expected that the frequency of two- and five-year inter-calf intervals combined may be more representative of the level of early infant mortality within the population. When combined, two- and five-year inter-calf intervals represented $9 \%$ of all intervals observed in the wider Australian population during this study. It should be noted that any such analysis will be biased by the apparent presence in the population of a small proportion of females whose reproductive cycle is four years. Such females may shorten their calving interval upon the early loss of a calf by reverting to the 'normal' three-year interval.

Knowlton et al. (1994) provide data on the frequency of occurrence of various calving intervals in the North Atlantic right whale population. The incidence of five-year inter-calf intervals in this population $(16.3 \%)$ is exceeded only by three-year intervals and is substantially higher than the frequency of five-year intervals detected in this study $(6.8 \%)$, or off South Africa (4.8\%) by Best (1990a). Further, the combined incidence of two- and five-year inter-calf intervals in the western North Atlantic of $17.5 \%$ is almost twice as high as that recorded in this study (9.4\%).

The failure of the North Atlantic right whale population to recover from exploitation has been cause for some concern (e.g. Knowlton et al., 1994; IWC, 2001a). The high incidence of five-year inter-calf intervals observed within the North Atlantic population may be indicative of a higher proportion of unsuccessful calvings and the reduced fecundity of that population (National Marine Fisheries Service, 2000).

The mean age at which weaning had occurred for the 18 individuals recorded during this study is based on more substantial data than any previous published estimates for the species. The observation that some females will return with their year-old calves to their calving site supports similar observations made by Thomas and Taber (1984) at Peninsula Valdes. However, it is clear that in the present study this behaviour is perhaps the exception rather than the rule. Only a small number of females were resighted at the Head of Bight aggregation area in a weaning year, despite the substantial survey coverage and photo-identification effort that were achieved in this study. In addition, the resighting of three yearlings off the Australian coast, a considerable distance from their birth site, may mean that these individuals were left to navigate their return journey from the feeding grounds alone, or that their cows 'deposited' them at the coast at these other areas. Either way, it is clear that some juveniles become familiar with quite widely separated locations on the Australian coastline as early in life as their second winter.

\section{Coastal movement}

Despite the apparent over-representation of females in the coastal movements documented (53\% versus $24 \%$ ) it is unlikely that females make significantly more coastal movements than males. This discrepancy probably reflects the greater chance of photographically identifying females, and the greater ease with which identified individuals can be sexed as female. This identification bias is due to the longer residence periods within coastal aggregation areas of calving females than those of unaccompanied whales (Burnell and Bryden, 1997), with an associated increased likelihood of them being photographed, combined with the additional benefit of being able to determine the sex of a mature female on the basis of its continued accompaniment by a neonatal calf as well as via direct observation of the ano-genital configuration. In support of this explanation, the observed representations of the sex-classes in the movements recorded are not significantly different from the proportion at which each sex-class is represented in the Head of the Bight identification catalogue; viz. females $55 \%$, males $21 \%$ and unknown sex $24 \%,\left(\chi^{2}=3.35, p>0.15\right)$.

Due to differences in the effort applied to the collection of identifications within different regions and in different years, it is hard to draw any conclusions about trends or changes in coastal distribution from these data. Of the 14 changes of calving location made by the 13 females, eight were made in an easterly direction and six to the west. These data are more interesting in light of the strong fidelity to calving locations displayed by the species (Best, 1981; 1990b; Bannister, 1990; Payne et al., 1990). It is clear that in this population some females do alter their calving location between subsequent calves, although the reasons are not known. Rarely, females show a lack of intra-year fidelity to a particular locality within a calving year, being observed to move considerable distances around the coastline with their calves during a single winter-spring season, for example individual 9409.

Movements of individually identified whales have been used in several areas to infer stock identity (e.g. Kraus et al., 1986b; Donovan, 1991; IWC, 2001b). A total of 63 movements between the southwest region and the south central region have been documented in the present study ( $n=7$ within-years; $n=56$ between-years). Given this degree of interchange, the likelihood of any meaningful population division between these regions appears remote. However, considerable fidelity was shown by mature females to specific aggregation sites during their calving years.

A further 25 movements between the southeastern Australian region and the south central region, and seven movements between the southeast region and southwest Australian regions have been documented. Although the number of movements detected to and from the southeast Australian region is substantially lower than for the other regions, it is worthy of note. The reduced level of interchange so far detected with the southeast region is more likely to be a factor of the limited research effort within that region compared with the other two regions than of any real population sub-division. This interpretation is supported by the fact that a concerted effort to obtain photo-identifications from southeastern Australia in 1995 nearly doubled the number of movements to and from that region in a single season (Burnell and McKenna, 1996).

A significant difference between the proportion of movements made in each direction existed between withinand between-year movements (Kruskall-Wallis ANOVA, $H=16.9, \quad p<0.001)$. Twenty-four percent of the between-year movements were made in a westerly direction, while $95 \%$ of the within-year movements were made in that direction. A migration pattern off southeastern Australia involving coastal movement being predominantly westerly was proposed as early as 1842 in written accounts of the 'black' whale fishery at that time, and was presumably based on the temporal and spatial distribution of coastal catches of right whales (Newland, 1921; Cumpston, 1970). Between-year resightings in coastal waters are likely to have been separated by an oceanic, latitudinal migration to the feeding grounds, meaning the only true coastal movements are likely made within years.

The results of this study, based on the movements of individually-identified whales, suggest that the great majority (95\% in this study) of within-year movement on Australia's southern coastline takes place in a westerly direction. When combined with the high incidence of 
between-year movements that were made to the east (76\%), the possibility of an almost circular, anti-clockwise migration for this species to the south of Australia is suggested. Fig. 3 shows the predicted seasonal migration of right whales to the south of Australia.

The movement patterns of right whales off the east coast of Australia, and in the Tasman Sea, are not known and may not relate to those presented here. However, the limited data available suggest that right whales using this region may follow a similar movement pattern to that proposed for the population as a whole. The only within-year movement that has been detected to date involving a whale sighted off the New South Wales coastline was made to the southwest, through Bass Strait to western Victoria (Burnell and McKenna, 1996). Similarly, a record exists of a within-year movement between the east coast of Tasmania and Western Victoria, presumably made in a northwesterly direction through Bass Strait (Burnell, 1997).

Mate et al. (1997), using satellite telemetry, showed that North Atlantic right whales can cover large distances $(>3,000 \mathrm{~km})$ visiting several different locations in between consecutive sightings at surveyed aggregation areas such as the Bay of Fundy. It is clear that many of the movements detected in this study would have involved travel over much longer distances than those reported and that unaccompanied whales that are consecutively sighted at the same location within a season may have left and returned to those sites between sightings.

However, these records of substantial amounts of coastal movement strongly suggest that the right whales utilising the Australian coastline represent a single stock, within which individuals may show strong fidelity to particular regions. Further, they emphasise the fact that regional conservation initiatives, such as the recent declaration of the Head of the Bight whale sanctuary and Marine Park, are of considerable importance to the entire Australian population.

\section{Fidelity to the Head of Bight aggregation area}

Despite being seen intermittently at widely separated locations, some individuals show strong fidelity to specific coastal aggregation areas, in particular mature females in their calving years. Fidelity to a geographic area, in the context being proposed, does in no way imply the exclusive use of that area by an individual whale. The large scale whale migrations, and the distribution of their prey, imply that the range of an individual right whale will be vast. However, the
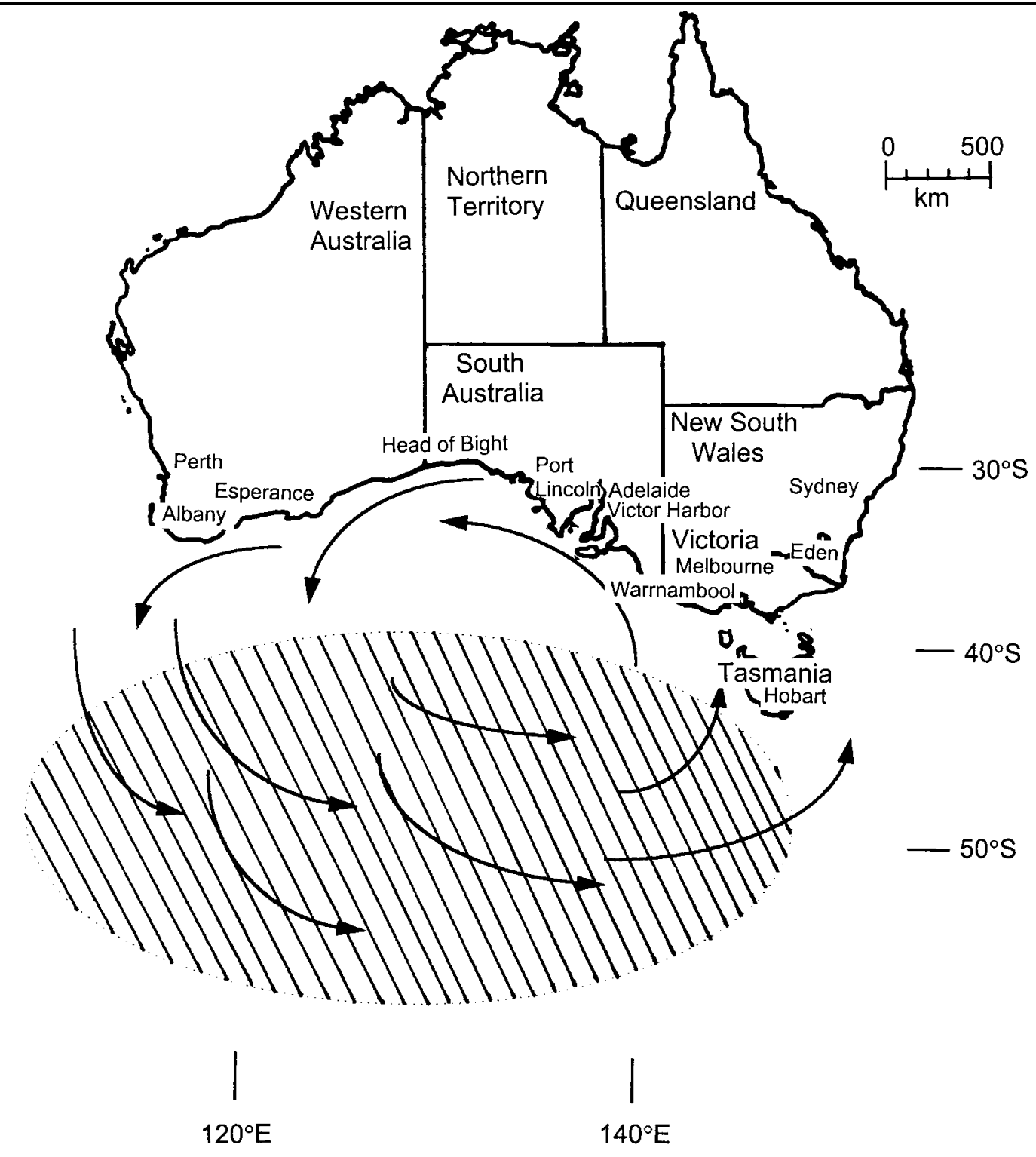

Fig. 3. The predicted seasonal migration of right whales to the south of the Australian continent, broadly based on movements of identified individual right whales. Hatched area likely feeding grounds. 
consistent and repetitive (albeit intermittent) use of specific areas, often for a specific purpose such as breeding or feeding, can be considered a level of fidelity (e.g. Donovan, 1986). Whilst breeding females have been recorded returning repetitively to calve at locations on the coastlines of Argentina, South Africa and Western Australia (Payne, 1986; Bannister, 1990; Best, 1990a), almost nothing is known of the fidelity of non-calving whales to these coastal regions or of the geographic scale on which fidelity is displayed.

It was impossible to quantify the effort expended in the collection of photo-identification data used in this analysis of fidelity, meaning that comparisons between different regions and different years will be unavoidably biased and were therefore not attempted. However, a comparison between the relative fidelity of different age, sex and reproductive classes to the Head of the Bight is both meaningful and achievable since any bias between areas or years that does exist can be expected to impact relatively equally across these various classes. If a bias favouring detection of a particular age or sex class does exist, it would tend to act against the sighting of unaccompanied whales at locations other than the Head of the Bight, due to the infrequent survey regimes in those areas and the shorter coastal residence of unaccompanied whales (Bannister, 1997; Burnell and Bryden, 1997). Such a bias would have the effect of exaggerating the relative fidelity of unaccompanied whales to the Head of the Bight, thereby acting to reduce the differences in relative fidelity detected in this analysis.

Non-calving (unaccompanied) whales showed a significantly lower relative fidelity to the Head of the Bight than did mature females known to have calved at the site (Yates corrected $\left.\chi^{2}=9.29, p<0.005\right)$. Further, males showed significantly lower relative fidelity to the Head of the Bight aggregation area than did females (both calving and non-calving) or juveniles. These data reinforce the possibility that males are indeed more transient in coastal waters, visiting a range of different localities and spending less time in particular aggregation areas. The predicted polygamous (in essence it is both polyandrous and polygynous) mating strategy (Brownell and Ralls, 1986; pers. obs.) and the documented fidelity of mature females to calving localities (possibly leading to matrilineal 'sub-populations') supports such a scenario, whereby the more transient males may provide the dispersal and genetic 'mixing' throughout the wider population. The very low fidelity of unsexed whales to the Head of the Bight is probably due to this group being predominantly male. This is suspected to be due to the increased difficulty in determining the gender of males and because the majority of gender determination during this study was achieved at the Head of the Bight, meaning whales showing the least fidelity to that site could be expected to have the least chance of having their gender determined.

\section{ACKNOWLEDGEMENTS}

I would like to thank the many volunteers, too numerous to mention individually, who have provided assistance with the field work on this project. The Yalata Aboriginal Community graciously allowed access to their land at the Head of the Bight. John Bannister provided access to his extensive catalogue of identification photographs from Western Australia and his advice has greatly benefited this work. Many people have given valuable assistance and/or provided identification photographs including Michael Bryden, Peter Corkeron, Pin Needham, Cath Kemper,
Rebecca Pirzl, Margie Morrice and Ian Westhorpe. The Victorian, South Australian, New South Wales and Tasmanian National Park Services were all supportive of the southeast Australian flight network and provided the necessary permits for the flights. I am grateful to John Bannister, Peter Corkeron, Peter Best and Steve Katona for their advice on improving this manuscript and to Environment Australia, BHP Petroleum Pty. Ltd., Esso Australia Ltd. and Eubalaena Pty. Ltd. for their financial support of these studies.

\section{REFERENCES}

Bannister, J.L. 1990. Southern right whales off western Australia. Rep. int. Whal. Commn (special issue) 12:279-88.

Bannister, J.L. 1997. Aerial survey of southern right whales off Western and South Australia, 1995 and 1996 calving seasons: report on work undertaken to 1 March 1997. Unpublished report to the Australian Nature Conservation Agency, Canberra. 27pp. [Available from: www.environment.gov.au/library/pubs].

Bannister, J.L., Kemper, C.M. and Warneke, R.M. 1996. Wildlife Australia, Endangered Species Program. The Action Plan for Australian Cetaceans. Project Number 30. Australian Nature Conservation Agency, Canberra. 242pp. [Available from: www.environment.gov.au/library/pubs].

Bannister, J.L., Pastene, L.A. and Burnell, S.R. 1999. First record of movement of a southern right whale (Eubalaena australis) between warm water breeding grounds and the Antarctic Ocean, South of $60^{\circ}$ S. Mar. Mammal Sci. 15(4):1337-42.

Best, P.B. 1981. The status of right whales (Eubalaena glacialis) off South Africa, 1969-1979. Investl Rep. Div. Sea Fish. S. Afr. 123:1-44.

Best, P.B. 1990a. Natural markings and their use in determining calving intervals in right whales off South Africa. S. Afr. J. Zool. 25(2):114-23.

Best, P.B. 1990b. Trends in the inshore right whale population off South Africa, 1969-1987. Mar. Mammal Sci. 6(2):93-108.

Best, P.B. 1994. Seasonality of reproduction and the length of gestation in southern right whales Eubalaena australis. J. Zool., Lond. 232:175-89.

Best, P.B. and Rüther, H. 1992. Aerial photogrammetry of southern right whales, Eubalaena australis. J. Zool., London. 228:595-614.

Best, P.B., Payne, R., Rowntree, V., Palazzo, J.T. and Both, M.D. 1993. Long-range movements of South Atlantic right whales Eubalaena australis. Mar. Mammal Sci. 9(3):227-34.

Best, P.B., Brandão, A. and Butterworth, D. 2001. Demographic parameters of southern right whales off South Africa. J. Cetacean Res. Manage. (special issue) 2:161-169.

Braham, H.W. and Rice, D.W. 1984. The right whale, Balaena glacialis. Mar. Fish. Rev. 46:38-44.

Brownell, R.L. and Ralls, K. 1986. Potential for sperm competition in baleen whales. Rep. int. Whal. Commn (special issue) 8:97-112.

Brownell, R.L., Best, P.B. and Prescott, J.H. (eds.). 1986. Report of the International Whaling Commission (Special Issue 10). Right Whales: Past and Present Status. International Whaling Commission, Cambridge, UK. vi+289pp.

Burnell, S.R. 1997. An incidental flight network for the photo-identification of southern right whales off southeastern Australia. A summary of research activities undertaken in the 1995 and 1996 seasons. Report by Eubalaena Pty. Ltd to BHP Petroleum Pty. Ltd. and Esso Australia Ltd. 30pp. [Available from: sburnell@bigfoot.com].

Burnell, S.R. and Bryden, M.M. 1997. Coastal residence periods and reproduction timing in southern right whales (Eubalaena australis). J. Zool., Lond. 241:613-21.

Burnell, S. and McKenna, T. 1996. An incidental flight network for the photo-identification of southern right whales off southeastern Australia. Report to BHP Petroleum Pty. Ltd. 30pp. (Unpublished). [Available from: sburnell@bigfoot.com].

Chittleborough, R.G. 1958. The breeding cycle of the female humpback whale, Megaptera nodosa (Bonnaterre). Aust. J. Mar. Freshwater Res. 9(1):1-18 + 4pls

Cooke, J.G., Rowntree, V. and Payne, R. 2001. Estimates of demographic parameters for the southern right whales (Eubalaena australis) observed off Peninsula Valdés, Argentina. J. Cetacean Res. Manage. (special issue) 2:125-132.

Cumpston, J.S. 1970. Kangaroo Island 1800-1836. Roebuck, Canberra. 197pp. 
Darling, J.D. 1984. Gray whales off Vancouver Island, British Columbia. pp. 267-87. In: M.L. Jones, S.L. Swartz and S. Leatherwood (eds.) The Gray Whale, Eschrichtius robustus. Academic Press, Orlando, Florida. xxiv+600pp.

Dawbin, W.H. 1986. Right whales caught in waters around south eastern Australia and New Zealand during the nineteenth and early twentieth centuries. Rep. int. Whal. Commn (special issue) 10:261-7.

Donnelly, B.G. 1969. Further observation on the southern right whale, Eubalaena australis, in Southern African waters. J. Reprod. Fertil., Suppl. 6:347-52.

Donovan, G.P. (ed.). 1986. Report of the International Whaling Commission (Special Issue 8). Behaviour of Whales in Relation to Management. International Whaling Commission, Cambridge, UK. 282pp.

Donovan, G.P. 1991. A review of IWC stock boundaries. Rep. int. Whal. Commn (special issue) 13:39-68.

Hamilton, P.K., Marx, M.K. and Kraus, S.D. 1995. Weaning in North Atlantic right whales. Mar. Mammal Sci. 11(3):386-90.

International Whaling Commission. 2001a. Report of the Workshop on Status and Trends of Western North Atlantic Right Whales. J. Cetacean Res. Manage. (special issue) 2:61-87.

International Whaling Commission. 2001b. Report of the Workshop on the Comprehensive Assessment of Right Whales: A worldwide comparison. J. Cetacean Res. Manage. (special issue) 2:1-60.

Jones, M.-L. 1990. The reproductive cycle in gray whales based on photographic resightings of females in the breeding grounds from 1977-82. Rep. int. Whal. Commn (special issue) 12:177-82.

Klumov, S.K. 1962. Gladkie (Yaponskie) kity Tikhogo Okeana [The right whales in the Pacific Ocean]. Tr. Inst. Okeanol. Akad. Nauk SSSR 58:202-97. [In Russian].

Knowlton, A.R., Kraus, S.D. and Kenney, R.D. 1994. Reproduction in North Atlantic right whales (Eubalaena glacialis). Can. J. Zool. 72(7):1,297-305.

Kraus, S.D., Moore, K.E., Price, C.A., Crone, M.J., Watkins, W.A., Winn, H.E. and Prescott, J.H. 1986a. The use of photographs to identify individual North Atlantic right whales (Eubalaena glacialis). Rep. int. Whal. Commn (special issue) 10:145-51.

Kraus, S.D., Prescott, J.H., Knowlton, A.R. and Stone, G.S. 1986 b. Migration and calving of right whales (Eubalaena glacialis) in the western North Atlantic. Rep. int. Whal. Commn (special issue) 10:139-44.

Kraus, S., Hamilton, P., Kenney, R., Knowlton, A. and Slay, C. 2001 Reproductive parameters of the North Atlantic right whale. $J$. Cetacean Res. Manage. (special issue) 2:231-236.

Ling, J.K. and Needham, D.J. 1985-1990. Annual Reports to Australian National Parks and Wildlife Service (Environment Australia). Australian Nature Conservation Agency, Canberra. (Unpublished). [Available from: www.environment.gov.au/library/pubs].

Ling, J.K. and Needham, D.J. 1991. Southern right whales survey: South Australian calving season. Final Report to the Australian Nature Conservation Agency (Annual Reports to Australian National
Parks and Wildlife Service). (Unpublished). 17pp. [Available from: www.environment.gov.au/library/pubs].

Lockyer, C. 1984. Review of baleen whale (Mysticeti) reproduction and implications for management. Rep. int. Whal. Commn (special issue) 6:27-50.

Mate, B.R., Nieukirk, S.L. and Kraus, S.D. 1997. Satellite-monitored movements of the northern right whale. J. Wildl. Manage. 61(4):1393-405.

National Marine Fisheries Service. 2000. Report of the Workshop on the Causes of Reproductive Failure in North Atlantic Right Whales: New avenues of research. Falmouth, Massachusetts, 26-28 April 2000. Paper SC/52/OS14 presented to the IWC Scientific Committee, June 2000, in Adelaide, Australia. [Paper available from the Office of this Journal].

Newland, S. 1921. Report on whaling in South Australia. Proc. Roy. Geog. Soc. Aust. 22 (S.A. Branch):25-34.

Payne, R. 1986. Long term behavioral studies of the southern right whale (Eubalaena australis). Rep. int. Whal. Commn (special issue) 10:161-7.

Payne, R. and Dorsey, E.M. 1983. Sexual dimorphism and aggressive use of callosities in right whales (Eubalaena australis). pp. 295-329. In: R. Payne (ed.) Communication and Behavior of Whales. AAAS Selected Symposium 76. Westview Press, Boulder, Colorado. xii+643pp.

Payne, R., Brazier, O., Dorsey, E.M., Perkins, J.S., Rowntree, V.J. and Titus, A. 1983. External features in southern right whales (Eubalaena australis) and their use in identifying individuals. pp. 371-445. In: R. Payne (ed.) Communication and Behavior of Whales. AAAS Selected Symposia Series 76. Westview Press, Colorado. xii+643pp.

Payne, R., Rowntree, V., Perkins, J.S., Cooke, J.G. and Lankester, K. 1990. Population size, trends and reproductive parameters of right whales (Eubalaena australis) off Peninsula Valdes, Argentina. Rep. int. Whal. Commn (special issue) 12:271-8.

Rice, D.W. and Wolman, A.A. 1971. The Life History and Ecology of the Gray Whale (Eschrichtius robustus). American Society of Mammalogists, Special Publication No. 3, Stillwater, Oklahoma. viii+142pp.

Thomas, P.O. and Taber, S.M. 1984. Mother-infant interaction and behavioral development in southern right whales, Eubalaena australis. Behaviour 88(1-2):42-60.

Tormosov, D.D., Mikhalev, Y.A., Best, P.B., Zemsky, V.A., Sekiguchi, K. and Brownell Jr, R.L. 1998. Soviet catches of southern right whales, Eubalaena australis, 1951-1971; biological data and conservation implications. Biol. Conserv. 86(2):185-97.

Yablokov, A.V. 1994. Validity of whaling data. Nature, Lond. 367(6459): 108.

Yablokov, A.V. and Bogoslovskaya, L.S. 1984. A review of Russian research on the biology and commercial whaling of the gray whale. pp. 465-85. In: M.L. Jones, S.L. Swartz and S. Leatherwood (eds.) The Gray Whale, Eschrichtius robustus. Academic Press Inc., Orlando, Florida. xxiv+600pp. 


\title{
Appendix 1
}

\section{TABLES DETAILING THE WITHIN- AND BETWEEN-YEAR COASTAL MOVEMENTS RECORDED, INCLUDING DATE AND LOCATION OF RELEVANT SIGHTINGS AND THE SEX AND STATUS OF INDIVIDUALS IN 1995, IF KNOWN}

\author{
Table 1
}

The 18 within-year movements of individual right whales recorded during this study. Key: $\Lambda$ - Unaccompanied adult; C/Ca - Cow/calf pair; HOB - Ilead

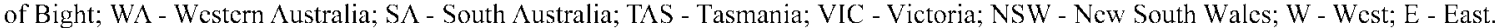

\begin{tabular}{|c|c|c|c|c|c|c|}
\hline ID No. & Sex & $\begin{array}{l}\text { Sighting locality } 1 \text {, including date, photo } \\
\text { number and status }\end{array}$ & $\begin{array}{l}\text { Sighting locality } 2 \text {, including date, photo } \\
\text { number and status }\end{array}$ & $\begin{array}{l}\text { Distance } \\
(\mathrm{km})\end{array}$ & $\begin{array}{l}\text { Days } \\
\text { apart }\end{array}$ & Direction \\
\hline 9143 & ? & 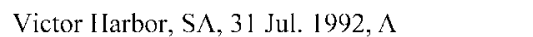 & HOB, SA. 26 Aug. $1992, \Lambda$ & 950 & 26 & W \\
\hline 9203 & $\mathrm{~F}$ & 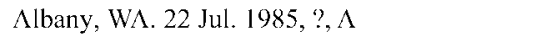 & Stokes Inlet, WA. 2 Sep. 1985, ?, $\Lambda$ & 326 & 42 & $\mathrm{E}$ \\
\hline 9228 & $\mathrm{~F}$ & 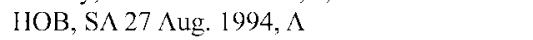 & Pt D'Entrecastcaux, WA. 7 Oct. 1994, $18, \Lambda$ & 1,490 & 41 & W \\
\hline 9321 & $\mathrm{~F}$ & HOB, SA. 27 Sep. $1993, \mathrm{C} / \mathrm{Ca}$ & Eucla, WN. $30 \mathrm{Scp} .1993, \mathrm{C} / \mathrm{Ca}$ & 211 & 3 & $\mathrm{~W}$ \\
\hline 9325 & $\mathrm{~F}$ & Mississippi Bay, WA. 17 Sep. 1983,?, $\Lambda$ & Cape Barren, WA. 30 Sep. 1983, 3-6 2a, $\Lambda$ & 280 & 13 & $\mathrm{E}$ \\
\hline 9357 & $\mathrm{~F}$ & Kangaroo Island, S $\Lambda .16$ Jun. $1993, \mathrm{~S} \Lambda \mathrm{M}, \Lambda$ & HOB, SA. 30 Jul. $1993, \Lambda$ & 788 & 44 & W \\
\hline 9394 & M & HOB, SA. 11 Aug. 1994, A & Yokinup Bay, WA. 29 Sep. 1994, A & 840 & 49 & W \\
\hline 9409 & $\mathrm{~F}$ & Port Lincoln, SA. 3 Aug. $1994, \mathrm{C} / \mathrm{Ca}$ & HOB, S $\Lambda .3$ Sep. $1994, \mathrm{C} / \mathrm{Ca}$ & 704 & 31 & W \\
\hline 9420 & M & Capc Barren, WA. 16 Aug. 1985, A & Augusta, WA. I Scp. $1985, \Lambda$ & 495 & 16 & $\mathrm{~W}$ \\
\hline 9423 & $?$ & HOB, SA. 16 Jul. 1994, А & Rossiter Bay, WA. 8 Aug. 1994, R4 8, A & 851 & 23 & W \\
\hline 9425 & ? & HOB, S $\Lambda .18$ Jul. $1994, \Lambda$ & Yokinup Bay, WA. 6 Scp. 1994, $103, \Lambda$ & 840 & 59 & $\mathrm{~W}$ \\
\hline 9432 & $\mathrm{~F}$ & HOB, SA. 31 Jul. 1994, A & 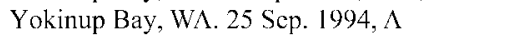 & 840 & 56 & $\mathrm{~W}$ \\
\hline 9452 & ? & Portland, VIC. 22 Jul. 1994, A & HOB, SA. 18 Sep. 1994, A & 1,297 & 58 & W \\
\hline 9532 & ? & HOB, SA. 14 Jul. $1995, \Lambda$ & Bremer Bay, WA. 11 Sep. 1995,4 10, $\Lambda$ & 1,148 & 59 & $\mathrm{~W}$ \\
\hline $95 \mathrm{FN} 3$ & ? & Nelson, VIC. 25 May 1995, A & Anglesca, VIC. 29 May $1995, \Lambda$ & 351 & 4 & $\mathrm{E}$ \\
\hline $95 \mathrm{FN} 4$ & ? & Eden, NSW. 28 Aug. 1995, Butt, $\Lambda$ & Apollo Bay, VIC. 23 Sep. $1995, \Lambda$ & 689 & 26 & $\mathrm{~W}$ \\
\hline 95FN5 & ? & 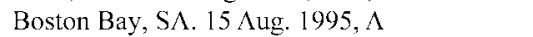 & HOB, SA. 12 Sep. $1995,251, \Lambda$ & 704 & 28 & W \\
\hline \multirow[t]{2}{*}{$95 \mathrm{FN} 6$} & ? & The Bluff, Victor I Iarbor, SA. 20 Jul. 1995, $\Lambda$ & Boston Bay, SA. 15 Aug. 1995, A & 327 & 26 & $\mathrm{~W}$ \\
\hline & & & Mcan $(n=18)$ & 729.5 & 33.56 & \\
\hline
\end{tabular}


Table 2

The 90 between-year movements made by individual right whales during this study. Key: $\Lambda$ - Unaccompanied adult; C/Ca - Cow/calf pair; IHOB - Iead of Bight; WA - Western Australia; SA - South Australia; TAS - Tasmania; VIC - Victoria; NSW - New South Wales; W - West; E - East.

\begin{tabular}{|c|c|c|c|c|c|c|}
\hline ID No. & Sex & $\begin{array}{l}\text { Sighting locality } 1 \text {, including date, photo } \\
\text { number and status }\end{array}$ & $\begin{array}{l}\text { Sighting locality } 2 \text {, including date, photo } \\
\text { number and status }\end{array}$ & $\begin{array}{l}\text { Distance } \\
(\mathrm{km})\end{array}$ & $\begin{array}{l}\text { Years } \\
\text { apart }\end{array}$ & Dircction \\
\hline 9104 & $\mathrm{~F}$ & $\mathrm{HOB}, \mathrm{SA}, 1988, \mathrm{C} / \mathrm{Ca}$ & Augusta, WA, 1990,? & 1,529 & 2 & W \\
\hline 9104 & $\mathrm{~F}$ & Augusta, WA, 1990,? & IHOB, SA, 10 Oct. $1991, \mathrm{C} / \mathrm{Ca}$ & 1,529 & 1 & $\mathrm{E}$ \\
\hline 9105 & $\mathrm{~F}$ & Dillon Bay, WA, $16 \Lambda$ ug. $1986,9-1211, \Lambda$ & HOB, SA, Aug. 1988, DJN 88/7/9, C/Ca & 1,149 & 2 & $\mathrm{E}$ \\
\hline 9115 & $\mathrm{~F}$ & Pt Anne, WA, 6 Aug. 1983, 1-3 10, A & IHOB, SA, 27 Sep. $1991, \mathrm{C} / \mathrm{Ca}$ & 1,125 & 8 & $\mathrm{E}$ \\
\hline 9115 & $\mathrm{~F}$ & IIOB, SA, 27 Sep. 1991, C/Ca & Yokinup Bay, WA, 6 Sep. 1994, 11 3, C/Ca & 808 & 3 & W \\
\hline 9116 & $\mathrm{~F}$ & Kangaroo Island, SA, 1986, DJN,? & IIOB, SA, 26 Aug. $1991, \mathrm{C} / \mathrm{Ca}$ & 780 & 5 & W \\
\hline $91 \mathrm{~b}$ & $\mathrm{~F}$ & Cape Riche, WA, 1986,? & HOB, SA, 21 Aug. $1991, \mathrm{C} / \mathrm{Ca}$ & 1,207 & 5 & E \\
\hline 9121 & $\mathrm{~F}$ & Augusta, WA, 15 Aug. $1985,1-3, \Lambda$ & Pt Anne, WA, 2 Sep. 1988, 1-5 4, C/Ca & 427 & 3 & $\mathrm{E}$ \\
\hline 9121 & $\mathrm{~F}$ & Pt Anne, WA, 2 Sep. $1988,1-54, \mathrm{C} / \mathrm{Ca}$ & HOB, SA, 1 Sep. 1991, A & 1,103 & 3 & $\mathrm{E}$ \\
\hline 9129 & $\mathrm{~F}$ & IHOB, SA, 22 Jul. $1992, \Lambda$ & Albany, WA, 5 Sep. $1994,313,48, \Lambda$ & 1,294 & 2 & W \\
\hline 9129 & $\mathrm{~F}$ & Albany, WA, 5 Sep. 1994,3 13, 48, A & HOB, SA, 10 Sep. 1995, A & 1,294 & 1 & $\mathrm{E}$ \\
\hline 9135 & M & HOB, SA, 19 Jul. 1994, A & Tagon Bay, WA, 3 Aug. 1995, 10 5-7, $\Lambda$ & 810 & 1 & W \\
\hline 9201 & $\mathrm{~F}$ & Pt Lincoln, SA, 1976, DJN, A & Pt Charles, WA, 24 Aug. 1984, 1 12, A & 1,478 & 8 & W \\
\hline 9201 & $\mathrm{~F}$ & Pt Charles, WA, 28 Scp. $1986,53 \mathrm{~b}, \mathrm{C} / \mathrm{Ca}$ & IHOB, SA, $1989, \mathrm{DJN}, \mathrm{C} / \mathrm{Ca}$ & 1,103 & 3 & $\mathrm{E}$ \\
\hline 9203 & $\mathrm{~F}$ & Albany, WA, 22 Jul. 1985, 1-2 3,? & HOB, SA, 8 Jul. $1992, \mathrm{C} / \mathrm{Ca}$ & 1,294 & 7 & $\mathrm{E}$ \\
\hline 9205 & $\mathrm{~F}$ & $?$, WA, 1980, Sep 80 b $13-14$ & HOB, SA, 1986, DJN & $?$ & 6 & $\mathrm{E}$ \\
\hline 9205 & $\mathrm{~F}$ & HOB, SA, 8 Scp. $1992, \mathrm{C} / \mathrm{Ca}$ & Israclite Bay, WA, 3 Aug. 1995, 12 1,C/Ca & 717 & 3 & $\mathrm{E}$ \\
\hline 9206 & $\mathrm{~F}$ & $?$, WA, 1983,? & HOB, SA, 1984,? & $?$ & 1 & E \\
\hline 9209 & $\mathrm{~F}$ & Sleaford Bay, SA, 1979, DJN,? & $\mathrm{HOB}, \mathrm{SA}, 1986, \mathrm{DJN}, ?$ & 571 & 7 & W \\
\hline 9210 & $\mathrm{~F}$ & HOB, SA, 1989, DJN,? & Yokinup Bay, WA, 16 Aug. 1990,612, A & 808 & 1 & W \\
\hline 9210 & $\mathrm{~F}$ & Yokinup Bay, WA, 16 Aug. 1990,612, A & HOB, SA, 27 Aug. $1992, \mathrm{C} / \mathrm{Ca}$ & 808 & 2 & $\mathrm{E}$ \\
\hline 9220 & $\mathrm{~F}$ & Pt Lincoln, SA, 1970, DJN,? & IHOB, SA, 1988, DJN, A & 567 & 18 & W \\
\hline 9222 & $?$ & Hassel Beach, WA, 28 Sep. 1990, $313, \Lambda$ & HOB, SA, 7 Jul. 1992, A & 1,241 & 2 & $\mathrm{E}$ \\
\hline 9222 & $?$ & HOB, SA, 7 Jul. 1992, A & Trigelow Beach, WA, 6 Sep. $1994,69, \Lambda$ & 1,103 & 2 & W \\
\hline 9227 & $?$ & HOB, SA, 26 Aug. 1992, A & Eden, NSW, 1 Sep. 1994, Butt, A & 1,834 & 2 & $\mathrm{E}$ \\
\hline 9236 & M & HOB, SA, 27 Sep. 1992, Ca & Eden, NSW, 2 Aug. 1993, Butt, $\Lambda$ & 1,834 & 1 & $\mathbf{E}$ \\
\hline 9302 & $\mathrm{~F}$ & Pt Charles, WA, 1 Oct. $1985,108, \mathrm{C} / \mathrm{Ca}$ & HOB, SA, 25 Jun. $1993, \mathrm{C} / \mathrm{Ca}$ & 1,103 & 8 & $\mathrm{E}$ \\
\hline 9308 & $\mathrm{~F}$ & HOB, SA, 24 Jun. 1994, C/Y & $42^{\circ} 02^{\prime} \mathrm{S}, 120^{\prime \prime} 30^{\prime} \mathrm{E} .14$ Dec. $1995, \mathrm{JLB}, \Lambda$ & 1,505 & 1.5 & SW \\
\hline 9310 & $\mathrm{~F}$ & Eucla, WA, 13 Aug. $1984,1-2$ 12, C/Ca & HOB, SA, 1990, DJN & 211 & 6 & $\mathrm{E}$ \\
\hline 9314 & $\mathrm{~F}$ & Israelite Bay, WA, 7 Jul. 1990, 4 5-6, A & HOB, SA, 3 Sep. $1993, \mathrm{C} / \mathrm{Ca}$ & 717 & 3 & $\mathrm{E}$ \\
\hline 9316 & $\mathrm{~F}$ & Hopetoun, WA, 9 Sep. 1987, Y 4, $\Lambda$ & HOB, SA, 23 Aug. $1993, \mathrm{C} / \mathrm{Ca}$ & 1,073 & 6 & E \\
\hline 9316 & $\mathrm{~F}$ & HOB, SA, 11 Jul. 1994, C/Y & Margaret Cove, WA, 3 Aug. 1995, 8 14-15, $\Lambda$ & 995 & 1 & W \\
\hline 9321 & $\mathrm{~F}$ & Twilight Cove, W $\Lambda, 17$ Sep. 1989, JLB 3 36,? & HOB, SA, 11 Aug. $1993, \mathrm{C} / \mathrm{Ca}$ & 489 & 4 & E \\
\hline 9325 & $\mathrm{~F}$ & Pt Charles, WA, 7 Aug. 1987, 5-16 $23 \mathrm{~b}, \Lambda$ & HOB, SA, 1989, SRB,? & 1,103 & 2 & $\mathrm{E}$ \\
\hline 9330 & $\mathrm{~F}$ & HOB, SA, 27 Jul. 1993, A & Twilight Cove, WA, $11 \mathrm{Sep} .1995,184, \mathrm{C} / \mathrm{Ca}$ & 489 & 2 & W \\
\hline 9331 & M & HOB, SA, 12 Aug. 1994, A & Wylie Scarp, WA, 11 Sep. 1995, 14 4, A & 540 & 1 & W \\
\hline 9335 & $?$ & Israelite Bay, WA, 15 Aug. 1991, $57 \& 11-12, A$ & HOB, SA, 4 Jul. 1993, $\Lambda$ & 717 & 2 & E \\
\hline 9339 & $\mathrm{~F}$ & Tagon Bay, WA, 2 Scp. $1988,1-1111, \Lambda$ & IHOB, SA, 11 Jul. $1993, \Lambda$ & 810 & 5 & $\mathrm{E}$ \\
\hline 93FB1 & $\mathrm{F}$ & Hassel Beach, WA, 22 Oct. 1990, $110, \mathrm{C} / \mathrm{Ca}$ & Fowlers Bay, SA, 18 Aug. 1993, C/Ca & 1,353 & 3 & E \\
\hline 9341 & M & Pt Charles, WA, 8 Aug. 1987, 4-8 10, A & Augusta, WA, 15 Aug. 1990, 17, A & 427 & 3 & W \\
\hline 9341 & M & Augusta, WA, 15 Aug. $1990,17, \mathrm{~A}$ & IOB, SA, 12 Jul. 1993, A & 1,529 & 3 & $\mathrm{E}$ \\
\hline 9344 & $\mathrm{~F}$ & HOB, SA, 18 Jul. $1993, A$ & Lucky Bay, WA, 4 Aug. 1995, 20 15, C/Ca & 884 & 2 & W \\
\hline 9346 & M & $\mathrm{HOB}, \mathrm{SA}, 1989, \mathrm{DJN}, \Lambda$ & Capc Ganthcaume, SA, 1992, SAM, A & 780 & 3 & $\mathrm{E}$ \\
\hline 9346 & M & Cape Gantheaume, SA, 13 Jul. 1992, SAM, A & HOB, SA, 29 Jul. 1993, A & 780 & 1 & W \\
\hline 9349 & $\mathrm{~F}$ & Dillon Bay, WA, 16 Aug. 1986, 9-12 7, A & HOB, SA, 1990, DJN O/21/27,? & 1,152 & 4 & $\mathrm{E}$ \\
\hline 9349 & $\mathrm{~F}$ & HOB, SA, 1990, DJN O/21/27,? & Pt Charles, WA, 3 Oct. 1992, JLB s $7-9, \mathrm{C} / \mathrm{Ca}$ & 1,103 & 2 & W \\
\hline 9349 & $\mathrm{~F}$ & Pt Charles, WA, 3 Oct. 1992 , JLB s $7-9, \mathrm{C} / \mathrm{Ca}$ & HOB, SA, 23 Jul. 1993, A & 1,103 & 1 & E \\
\hline 9351 & M & Scllicks Bch, $\mathrm{S} \Lambda, 1988, \mathrm{DJN}$ vidco, $\Lambda$ & IHOB, SA, 1990, DJN, A & 775 & 2 & W \\
\hline 9351 & M & $\mathrm{HOB}, \mathrm{SA}, 1990, \mathrm{DJN}, \Lambda$ & Coorong, SA, 1991, DJN, $A$ & 888 & 1 & E \\
\hline 9351 & M & Coorong, SA, 1991, DJN, A & HOB, SA, 4 Aug. 1993, A & 888 & 2 & W \\
\hline 9355 & M & HOB, SA, 25 Jul. 1994, A & Fishery Bay, $\mathrm{S} \Lambda, 6$ Sep. $1995, \Lambda$ & 575 & 1 & E \\
\hline 9357 & $\mathrm{~F}$ & $\mathrm{HOB}, \mathrm{S} A, 1990, \mathrm{DJN}, \Lambda$ & Kangaroo Island, $\mathrm{S} \Lambda, 1993, \mathrm{~S} A \mathrm{M}, \Lambda$ & 780 & 3 & $\mathbf{E}$ \\
\hline 9357 & $\mathrm{~F}$ & HOB, SA, 6 Jul. 1994, A & Anglesea, VIC, 31 May 1995, A & 1,420 & 1 & $\mathbf{E}$ \\
\hline 9358 & M & Pt Ann, WA, 20 Sep. 1980, 6a, A & IHOB, SA, 30 Jul. $1993, \Lambda$ & 1,103 & 13 & $\mathrm{E}$ \\
\hline 9360 & M & HOB, SA, 15 Nug. 1994, A & Apollo Bay, VIC, 28 Jul. 1995, A & 1,399 & 1 & $\mathbf{E}$ \\
\hline 9366 & $\mathrm{~F}$ & $\mathrm{HOB}, \mathrm{SA}, 1990, \mathrm{DJN}, \Lambda$ & Victor I larbor, SA, 1992, ?, $\Lambda$ & 831 & 2 & $\mathrm{E}$ \\
\hline 9366 & $\mathrm{~F}$ & Victor Harbor, SA, 1992,?, A & IHOB, SA, 25 Sep. 1993, A & 831 & 1 & W \\
\hline 9415 & $?$ & Hassel Beach, WA, 7 Sep. 1992, $38, \Lambda$ & $\mathrm{HOB}, \mathrm{SA}, 11 / 7 / 94, \mathrm{~A}$ & 1,241 & 2 & E \\
\hline 9418 & $\mathrm{~F}$ & Wray Bay, WA, 20 Aug. $1993,2110-11, A$ & IIOB, SA, 1 Aug. $1994, \Lambda$ & 1,190 & 1 & $\mathrm{E}$ \\
\hline 9420 & M & Albany, Wh, 19 Sep. $1985,1-12, \Lambda$ & Israelite Bay, WA, 1988, ?, A & 576 & 3 & $\mathrm{E}$ \\
\hline 9420 & M & Israclite Bay, WA, 1988, ?, $\Lambda$ & Augusta, WA, 2 Sep. $1990,15, \Lambda$ & 814 & 2 & W \\
\hline 9420 & M & Augusta, WA, 2 Sep. 1990, $15, \Lambda$ & IHOB, SA, 15 Jul. 1994, A & 1,529 & 4 & E \\
\hline 9424 & $?$ & Israelite Bay, WA, 28 Sep. $1990,72, \Lambda$ & HOB, SA, 17 Jul. 1994, $\Lambda$ & 717 & 4 & $\mathbf{E}$ \\
\hline 9428 & M & Albany, WA, 22 Jul. $1985,1-234, A$ & IIOB, SA, 9 Aug. $1994, \Lambda$ & 1,294 & 9 & $\mathrm{E}$ \\
\hline 9434 & M & Israelite Bay, WA, 3 Sep. 1990,12 14, A & IHOB, SA, 7 Aug. 1994, A & 717 & 4 & $\mathrm{E}$ \\
\hline 9434 & M & HOB, SA, 7 Aug. 1994, A & Twilight Cove, WA, 3 Aug. $1995,148, \Lambda$ & 489 & 1 & W \\
\hline 9441 & M & Hassel Beach, WA, 7 Sep. 1992, $33 \& 8, A$ & IHOB, SA, 29 Aug. $1994, \Lambda$ & 1,241 & 2 & $\mathrm{E}$ \\
\hline 9443 & $\mathrm{~F}$ & Albany, WA, 20 Aug. 1992,210, A & Israelite Bay, WA, 25 Sep. $1993,69-10, \Lambda$ & 576 & 1 & $\mathbf{E}$ \\
\hline 9443 & $\mathrm{~F}$ & Israclite Bay, WA, 25 Sep. 1993, $69-10, \Lambda$ & HOB, SA, 15 Sep. 1994, A & 717 & 1 & $\mathrm{E}$ \\
\hline 9450 & M & Dillon Bay, WA, 28 Sep. 1990,51, A & HOB, SA, 20 Sep. 1994, A & 1,152 & 4 & $\mathrm{E}$ \\
\hline 9455 & $\mathrm{~F}$ & Pt Charles, WA, 3 Oct. 1992, JLB S 31-32, A & IHOB, SA, 26 Sep. 1994, F & 1,103 & 2 & $\mathrm{E}$ \\
\hline 9456 & $?$ & Tagon Bay, WA, 1 Oct. $1985,19-29$ b3, A & IHOB, SA, 2 Oct. 1994, A & 810 & 9 & $\mathrm{E}$ \\
\hline
\end{tabular}


Table 2 continued.

\begin{tabular}{|c|c|c|c|c|c|c|}
\hline ID No. & Sex & $\begin{array}{l}\text { Sighting locality lincluding date, photo } \\
\text { number and status }\end{array}$ & $\begin{array}{l}\text { Sighting locality } 2 \text {, including date, photo } \\
\text { number and status }\end{array}$ & $\begin{array}{l}\text { Distance } \\
(\mathrm{km})\end{array}$ & $\begin{array}{l}\text { Years } \\
\text { apart }\end{array}$ & Direction \\
\hline 9458 & $?$ & Middleton, SA, 1991, DJN, A & HOB, SA, 4 Oct. 1994, A & 838 & 3 & W \\
\hline 9471 & M & $\mathrm{HOB}, \mathrm{SA}, 25$ Sep. $1994, \mathrm{Ca}$ & Wanna, SA, 27 Sep. 1995, A & 580 & 1 & $\mathrm{E}$ \\
\hline 9480 & M & HOB, SA, 28 Sep. $1994, \mathrm{Ca}$ & Semaphore, SA, 30 Aug. 1995, A & 780 & 1 & E \\
\hline $94 \mathrm{Y} 1$ & $\mathrm{~F}$ & Sellicks Bch, SA, 1983, DJN video, C/CA & Yokinup Bay, WA, 19 Sep. 1994, C/Ca & 1,423 & 11 & W \\
\hline $94 \mathrm{Y} 1$ & $\mathrm{~F}$ & Yokinup Bay, WA, 19 Sep. 1994, C/Ca & HOB, SA, 6 Jul. 1995, A & 808 & 1 & $\mathrm{E}$ \\
\hline $94 \mathrm{~F} 1$ & ? & Point Culver, WA, 17 Aug. $1993,82-3$, A & Swansea, TAS, 20 Jun. 1994, IN, A & 2,307 & 1 & E \\
\hline $94 \mathrm{~F} 1$ & $?$ & Swansea, TAS, 20 Jun. 1994, l'N, A & Wylie Scarp, WA, 11 Sep. $1995,147 \& 12$, A & 2,249 & 1 & W \\
\hline 9504 & $\mathrm{~F}$ & Tagon Bay, WA, 20 Oct. 1992, $411, \mathrm{C} / \mathrm{Ca}$ & $\mathrm{HOB}, \mathrm{SA}, 24$ Aug. $1995, \mathrm{C} / \mathrm{Ca}$ & 810 & 3 & E \\
\hline 9529 & $\mathrm{~F}$ & Cape Adieu, SA, 1986, DJN,? & Pl Anne, WA, 7 Sep. $1992,711 \& 13$, A & 1,215 & 6 & W \\
\hline 9529 & $\mathrm{r}$ & Pl Anne, WA, 7 Sep. $1992,711 \& 13$, A & HOB, SA, 9 Jul. 1995, A & 1,103 & 3 & $\mathrm{E}$ \\
\hline 9533 & $\mathrm{~F}$ & Logans Bch, VIC, Parer-Cook, DJN, C/CA & PL Charles, WA, 3 Oct. 1992 , JLB S 16, A & 2,086 & 10 & W \\
\hline 9533 & $\mathrm{~F}$ & Pi Charles, WA, 3 Oct. 1992, JLB S 16, A & HOB, SA, 14 Jul. 1995, A & 1,103 & 3 & $\mathrm{E}$ \\
\hline 9541 & $?$ & Lsperance, WA, 16 Aug. 1990, $519, \mathrm{~A}$ & HOB, SA, 23 Aug. 1995, A & 912 & 5 & $\mathrm{E}$ \\
\hline $95 \mathrm{FN} 1$ & $?$ & Albany, WA, 5 Sep. 1994,5 8-9, A & Cape T'ournefort, SA, 25/ Jul. 1995, A & 1,639 & 1 & $\mathrm{E}$ \\
\hline \multirow[t]{2}{*}{$95 \% \mathrm{~N} 2$} & $?$ & Yokinup Bay, WA, 6 Sep. 1994,11 10, A & Cape Tournefort, SA, 25 Jul. 1995, A & 1,187 & 1 & $\mathrm{E}$ \\
\hline & & & Mean $(n=90)$ & $?$ & 3.34 & \\
\hline
\end{tabular}

